\title{
ANALISA PERAN PARTISIPATIF DAN AKUNTABILITAS PERENCANAAN PEMBANGUNAN DESA (STUDI KASUS DESA SUMBERNGEPOH KECAMATAN LAWANG KABUPATEN MALANG)
}

\author{
Dekki Umamur Ra'is ${ }^{1}$ dan Yeni Tata Rini' \\ ${ }^{1}$ Fakultas Ilmu Sosial dan Ilmu Politik Universitas Tribhuwana Tunggadewi Malang \\ ${ }^{2}$ Fakultas Ekonomi Universitas Gajayana Malang \\ Email : deckyvanmaduro@gmail.com
}

\begin{abstract}
The process of implementing village development activities requires a good planning. In the preparation of development planning, the village government is required to be accountable and participatory, considering that this is the mandate of the Regulation. In addition the quality of village development will be determined by the extent of the role of the community in providing aspirations, implementing, monitoring, and evaluating the village development as well as the extent to which the village government is able to implement the values of accountability so that the community has access to information and data related to village development. This study using a qualitative approach. Primary data sources in this study were obtained through interviews with the objects interviewed, including: Pemerintahan Desa, Lembaga Pemberdayaan Masyarakat Desa, Badan Permusyawaratan Desa, Tokoh Perempuan, Tokoh Masyarakat, and Tokoh pemuda. Based on the results of the analysis of this study, it is known that the level of involvement of the villagers in Sumberngepoh in the process of planning, implementing, and monitoring development is still lower. Communities that should be involved have not been well involved, such as vulnerable groups, disabled people, marginal communities, the poor, and women are still not actively involved. While in terms of accountability, based on the results, it is known that the delivery of information related to the planning and implementation process of village development has started well, although there are many things need to be improved. Such as the process of submitting the reports related to the implementation of previously planned development.
\end{abstract}

Keywords : Participatory, Development Planning and Accountability.

\begin{abstract}
Abstrak: Proses pelaksananaan kegiatan pembanguna desa memerlukan perencanaan yang baik. Dalam penyusunan perencanaan pembangunan, pemerintah desa dituntut untuk akuntabel dan parisipatif, mengingat hal tersebut merupakan amanah UU Desa. Selain itu kualitas pembangunan desa akan ditentukan oleh sejauh mana peran masyarakat dalam memberikan aspirasi, melaksanakan, mengawasi, dan mengevaluasi pembangunan desa serta sejauh mana pemerintah desa mampu menerapkan nilai-nilai akuntabilitas sehingga masyarakat memiliki akses terhadap informasi dan data terkait pembangunan desa. Penelitian ini menggunakan pendekatan kualitatif. Sumber data primer dalam penelitian ini diperoleh melalui wawancara dengan objek yang diwawancarai, antara lain: Pemerintahan Desa, Lembaga Pemberdayaan Masyarakat Desa, Badan Permusyawaratan Desa, Tokoh Perempuan, Tokoh Masyarakat, dan Tokoh pemuda. Berdasarkan hasil analisa dari penelitian ini, diketahui bahwa tingkat keterlibatan warga Desa Sumberngepoh dalam proses perencanaan, pelaksanaan, dan pengawasan pembangunan masih belum maksimal.
\end{abstract}


Masyarakat yang sepatutnya terlibat belum terlibat dengan baik, seperti kelompok masyarakat rentan, difabel, masyarakat marjinal, masyarakat miskin, dan kaum perempuan masih belum terlibat secara aktif. Sementara dari sisi akuntabilitas, berdasarkan dari hasil anlisa diketahui bahwa penyampaian informasi terkait proses perencanaan dan pelaksaan pembangunan desa sudah mulai baik, walaupun masih banyak hal-hal yang perlu diperbaiki. Seperti proses penyampaian laporan terkait pelaksaan pembangunan yang telah direncanakan sebelumnya.

Kata Kunci : Partisipasi, Perencanaan Pembangunan dan Akuntabilitas.

\section{PENDAHULUAN}

Membangun kemandirian desa dalam kerangka Desa Membangun harus dimulai dari proses perencanaan desa yang baik, dan diikuti dengan tatakelola program yang baik pula. Pembangunan (pedesaan) yang efektif bukanlah semata-mata karena adanya kesempatan melainkan merupakan hasil dari penentuan pilihan-pilihan prioritas kegiatan, bukan hasil coba-coba, tetapi akibat perencanaan yang baik. Dalam konteks desa membangun, Kewenangan lokal berskala Desa telah diatur melalui Permendes PDTT No. 1 Tahun 2015, yang menyebutkan bahwa kriteria kewenangan lokal berskala Desa meliputi: a) kewenangan yang mengutamakan kegiatan pelayanan dan pemberdayaan masyarakat. b) kewenangan yang mempunyai lingkup pengaturan dan kegiatan hanya di dalam wilayah dan masyarakat Desa yang mempunyai dampak internal Desa. c) kewenangan yang berkaitan dengan kebutuhan dan kepentingan sehari-hari masyarakat Desa. d) kegiatan yang telah dijalankan oleh Desa atas dasar prakarsa Desa. e) program kegiatan pemerintah, pemerintah provinsi, dan pemerintah kabupaten/kota dan pihak ketiga yang telah diserahkan dan dikelola oleh Desa. f) kewenangan lokal berskala Desa yang telah diatur dalam peraturan perundang-undangan tentang pembagian kewenangan pemerintah, pemerintah provinsi, dan pemerintah kabupaten/kota.

Untuk melaksanakan kewenangan lokal bersakala desa tersebut, maka Pemerintah Desa perlu menyusun perencanaan desa yang melibatkan seluruh komponen masyarakat desa. Proses perencanaan yang baik akan melahirkan pelaksanaan program yang baik, dan pada gilirannya akan menumbuhkan partisipasi masyarakat untuk terlibat dalam pembangunan desa. Proses merencanakan, melaksanakan, dan mengevaluasi sendiri kegiatan pembangunan desa merupakan wujud nyata dari kewenangan mengatur dan mengurus pembangunan desa yang berskala lokal desa.

Perencanaan pembangunan desa mendorong partisipasi seluruh komponen masyarakat dalam pengambilan keputusan, termasuk kelompok miskin dan rentan di antaranya anak-anak, perempuan, lanjut usia, warga berkebutuhan khusus (disabilitas), sehingga pembangunan dapat dirasakan oleh semua pihak. Masyarakat desa juga berhak melakukan pemantauan terhadap pelaksanaan pembangunan desa. Penting bagi desa untuk memiliki perencanaan karena desa harus mengatur dan mengurus wilayah administratifnya sesuai dengan kewenangannya (self governing community). Perencanaan desa diharapkan dapat memperkuat hak dan kewenangannya sekaligus mengoptimalkan sumber kekayaan desa sebagai modal utama dalam pembangunan desa.

Peran aktif masyarakat dalam tata kelola pemerintahan desa mutlak dilakukan. Hal tersebut penting supaya pembangunan desa dilakukan secara tepat bagi kesejahteraan warga desa. Selain itu juga untuk mengurangi potensi persoalan dalam penggunaan dana desa dan 
tata kelola keuangan desa. Undang-Undang Nomor 6 Tahun 2014 tentang Desa (UU Desa) menjamin partisipasi aktif masyarakat. Dengan gamblang disebutkan salah satu dasar pengaturan desa didasarkan pada asas partisipasi. Dalam penjabarannya, terdapat enam pasal yang memberikan jaminan partisipasi warga (pasal 3,4,68,72,82, dan 94).

Partisipasi tidak sebatas dipahami dalam arti kehadiran, melainkan akses warga untuk menjadi pengambil keputusan mulai dari perencanaan, pelaksanaan, dan pengawasan. Hal tersebut penting untuk mendorong kinerja pemerintah desa yang demokratis. Untuk itu, pemerintah desa juga harus menjamin keterbukaan informasi.

Desa Sumberngepoh merupakan salah satu desa yang berada di Kecamatan Lawang. Desa Sumberngepoh merupakan salah satu desa yang memperoleh Dana Desa (DD) dan Alokasi Dana Desa (ADD). Dana Desa (DD) Merupakan dana hasil implementasi dari UU Desa Nomor 6 Tahun 2014 yang bersumber dari APBN yang diserahkan pengelolaannya oleh negara kepada Desa untuk kesejahteraan masyarakat. Demikian juga dengan Alokasi Dana Desa (ADD), bedanya ADD merupakan dana yang bersumber dari dana perimbangan daerah. Selain itu desa Sumberngepoh juga mendapat dana Bagi Hasil Pajak dan retribusi Daerah.

Semua sumber pendapatan yang dierima oleh desa harus digunakan untuk kepentingan pembangunan Desa. Dalam UU Desa penggunaan Dana Desa peruntukannya digunakan untuk empat bidang, yakni bidang penyelenggaraan pemerintahan Desa, pelaksanaan pembangunan Desa, pembinaan kemasyarakatan Desa dan pemberdayaan masyarakat Desa.

Proses pelaksananaan kegiatan pembanguna desa seperti disebutkan diatas memerlukan perencanaan yang baik. Dalam penyusunan perencanaan pembangunan, pemerintah desa dituntut untuk akuntabel dan parisipatif, mengingat hal tersebut merupakan amanah UU Desa. Selain itu kualitas pembangunan desa akan ditentukan oleh sejauh mana peran masyarakat dalam memberikan aspirasi, melaksanakan, mengawasi, dan mengevaluasi pembangunan desa serta sejauh mana pemerintah desa mampu menerapkan nilai-nilai akuntabilitas sehingga masyarakat memiliki akses terhadap informasi dan data terkait pembangunan desa. Untuk itu bagaimana peranan Masyarakat dan Pemerintahan Desa Sumberngepoh bersama-sama mendorong keterlibatan masyarakat serta mampu menerapkan prinsip-prinsip akuntabilitas sehingga bisa menghasilkan pembangunan desa yang berkualitas.

\section{METODE PENELITIAN}

Penelitian ini menggunakan pendekatan kualitatif. Menurut Moleong (2012) penelitian kualitatif adalah penelitian yang bermaksud untuk memahami fenomena tentang apa yang dialami oleh subjek penelitian misalnya prilaku, persepsi, motivasi, tindakan, dll., secara holistik, dan dengan cara deskripsi dalam bentuk kata-kata dan bahasa, pada suatu konteks khusus yang alamiah dan dengan memanfaatkan berbagai metode ilmiah.

Berdasarkan pemilihan jenis penelitian maka penelitian berusaha menajamkan pemahaman, penjelasan, dan Analisa Peran Partisipatif dan Akuntabilitas Perencanaan Pembangunan Desa (Studi Kasus Desa Sumberngepoh Kecamatan Lawang Kabupaten Malang).

Pada prosesnya penelitian ini mengumpulkan data dari sumber primer dan sekunder. Pengumpulan data dilakukan melalui proses observasi, wawancara, dan dokumentasi. Instrumen yang digunakan dalam penelitian ini adalah; peneliti sendiri, 
panduan wawancara (interview guide) dan catatan lapangan (field Note). Penentuan informan menggunakan metode Snow Ball Sampling dengan Informan kuncinya adalah Kepala Desa Sumberngepoh Kecamatan Lawang kabupaten Malang. Data yang diperoleh dari hasil observasi, wawancara dan dokumentasi kemudian diperiksa kabsahannnya menggunakan teknik triangulasi. Analisa data dilakukan dengan mengorganisasikan data, menjabarkan kedalam unit-unit, melakukan sintesa, menyusun kedalam pola, memilih mana yang penting dan mana yang akan dipelajari, dan membuat kesimpulan yang dapat diceritakan kepada orang lain. Setelah dilakukan pemeriksaan kebenaran, data kemudian dianalisa dengan menggunakan teknik reduksi, penyajian data, verifikasi, dan penarikan kesimpulan.

\section{PEMBAHASAN}

\section{Peran Partisipatif Masyarakat Desa}

Undang-Undang Nomor 6 Tahun 2014 tentang Desa (UU Desa) menjamin partisipasi aktif masyarakat. Secara jelas disebutkan salah satu dasar pengaturan desa didasarkan pada asas partisipasi. Dalam penjabarannya, terdapat enam pasal yang memberikan jaminan partisipasi warga (Pasal 3,4,68,72,82, dan 94).

Berdasarkan hasil kajian ini, diketahui bahwa dalam pelaksanaannya, tingkat keterlibatan masyarakat sudah semakin baik walaupun secara keseluruhan masih belum masif. Tingkat keterlibatan warga dalam setiap penyusunan perencanan maupun pelaksanaan pembangunan desa di Sumberngepoh dari tahun ke tahun terus mengalami peningkatan. Namun kondisi tersebut bukan berarti tidak ada hambatan. Dalam Sesi wawancara dengan beberapa perangkat desa dan tokoh masayarakat, walaupun sudah ada upaya kuat yang dilakukan oleh Pemerintahan Desa Sumberngepoh untuk meningkatkan keterlibatan warga desa, upaya pelibatan masyarakat masih menemui beberapa kendala dan hambatan. Kendala tersebut terjadi baik itu disisi pemerintahan desa sebagai penyelenggara maupun masyarakat desa sebagai pengguna (berkepentingan langsung dengan pembangunan desa). Pertama, dari sisi Pemerintahan Desa. Komunikasi yang intensif antara sesama warga masyarakat (horisontal) masih belum berjalan sebagaimana mestinya, hal tersebut dipengaruhi oleh perilaku masyarakat desa yang sebagiannya masih terjebak dalam friksi antar kelompok masyarakat desa Sumberngepoh sendiri. Selain itu, komunikasi antara warga masyarakat dengan pimpinan pemerintahan Desa secara keseluruhan masih belum berjalan dua arah. Komunisai hanya terjadi dengan sebagian elit warga desa saja.

Walaupun kondisi iklim sosial, ekonomi, politik dan budaya, baik dalam kehidupan keluarga, pergaulan, permainan, sekolah maupun masyarakat dan bangsa yang mendorong tumbuh dan berkembangnya partisipasi masyarakat sudah cukup baik di desa Sumberngepoh, nyatanya kondisi tersebut tidak berjalan lurus dengan praktek-praktek partisipasi masyarakat Desa. Dari hasil analisa, hal tersebut disebabkan belum terbukanya kesempatan (peluang) yang luas untuk berpartisipasi. Keadaan lingkungan dan struktur sosial desa Sumberngepoh yang masih didominasi oleh elit-elit desa serta sistem nilai dan norma-norma yang memungkinkan dan mendorong terjadinya partisipasi sosial hanya dilihat sebagai pemenuhan syarat normatif (menggugurkan kewajiban) dalam praktek pembangunan desa.

Selain itu walaupun sudah dibuka dan dijamin melalui regulasi bahwa keterlibatan masayarakat dalam pembangunan desa merupakan hal wajib, tingkat prakarsa dan 
keinginan berkreasi dikalangan masyarakat Sumberngepoh masih belum cukup baik, hal tersebut tentu saja mempengaruhi usaha-usaha yang dilakukan oleh Pemerintah Desa Sumberngepoh untuk meningkatkan partisipasi masyarakat desa. Berdasrkan analisa, faktor lingkungan di dalam keluarga, masyarakat atau lingkungan politik, sosial, budaya yang memungkinkan dan mendorong timbul dan berkembangnya prakarsa, gagasan, perseorangan atau kelompok, secara mayoritas masih belum kuat dikalangan warga desa Sumberngepoh.

Kedua, dari sisi masyarakat desa Sumberngepoh. Keinginan untuk berprakasrsa dan terlibat secara penuh dalam setiap kegiatan pembangunan desa masih rendah. Kendala tersebut diantaranya berkaitan dengan masalah umur, jenis kelamin, pendidikan, kepercayaan diri masyarakat, solidaritas dan integritas sosial masyarakat, tanggungjawab sosial dan komitmen masyarakat, kemauan dan kemampuan untuk mengubah atau memperbaiki keadaan dan membangun atas kekuatan sendiri.

Dari sisi umur, kondisi tersebut secara psikologis juga berpengaruh terhadap tingkat keterlibatan masyarakat desa. Terjadi perbedaan persepsi antara yang tua dengan yang muda. Warga masyarakat yang sudah tua beralasan bahwa keterlibatannya dalam pembangunan desa bukan masanya, bagi warga tua desa Sumberngepoh yang harus lebih aktif adalah warga desa yang lebih muda, karena dari sisi tenaga dan pemikiran lebih kuat. Sebaliknya, bagi sebagian pemuda desa, keterlibatan warga desa yang matang dari sisi usia masih diperlukan. Akibatnya warga desa yang masih muda merasa enggan untuk terlibat lebih jauh dalam kegiatan pembangunan. Faktor lainnya, berkaitan dengan prakarsa masyarakat atau prakarsa perseorangan yang diterima dan diakui sebagai atau menjadi milik masyarakat. Bagi sebagian masyarakat desa Sumberngepoh, kurangnya penghargaan dari pemerintah desa atas keterlibatan masyarakat membuat masyarakat pesimis, bahwa keterlibatan mereka hanya untuk memenuhi kebutuhan syarat normatif semata, bukan karena kebutuhan dan kepentingan masyarakat desa secara kesluruhan. Masyarakat desa Sumberngepoh masih melihat upaya yang dilakukan oleh Pemerintah Desa bukan karena kepentingan umum murni. Masyarakat desa Sumberngepoh melihatnya sebagai Kepentingan umum yang semu, karena masih adanya pencampuran kepentingan elit desa (perseorangan atau sebagian kecil dari masyarakat). Musyawarah untuk mufakat dalam pengambilan keputusan desa masih dipandang sebagai proses normatif, bukan untuk pertukaran gagasan, usulan, dan ide dari masyarkat.

Sebagian informan dari unsur masyarakat mengakui masalah akut lainnya dalam masyarakat desa Sumberngepoh adalah kepekaan dan daya tanggap masyarakat terhadap masalah, kebutuhan-kebutuhan dan kepentingan-kepentingan umum yang menyangkut masyarakat Desa Sumberngepoh. Hal tersebut disebabkan oleh masih rendahnya kesadaran warga desa sumberngepoh tentang pentingnya model pembangunan partisipatif bagi desa.

\section{Akuntabilitas Perencanaan Pembangunan Desa}

Akutanbilitas Perencanaan Pembangunan Desa menjadi sebuah keharusan di dalam penyelenggaraan Pemerintahan Desa, tujuan akuntabilitas dalam Perencanaan Pembangunan Desa adalah untuk memastikan setiap program dan kebijakan desa harus sesusai dengan kebutuhan desa serta memiliki nilai yang strategis untuk Desa. Nilai strategis dapat dilihat dari out put dan dampak perencanaan pembangunan Desa.

Guna memastikan perencanaan pembangunan desa dilaksanakan berdasarkan azasazas transparansi, akuntabel, partisipatif serta dilakukan dengan tertib dan disiplin 
anggaran. Pemerintah melalui UU Desa telah mengatur sedemikian rupa pelaksanaan perencanaan pembangunan Desa untuk menganut azas-azas tersebut.

Undang-Undang Nomor 6 Tahun 2014 Tentang Desa mengatur proses dan tahapan penyusunan dokumen perencanaan pembangunan Desa. Berdasarkan UU tersebut, perencanaan Desa meliputi RPJM Desa dan RKP Desa yang di susun secara berjangka dan ditetapkan melalui Peraturan Desa (Perdes). Rencana Pembangunan Jangka Menengah Desa (RPJMDesa) berlaku selama satu periode jabatan kepala desa yakni 6 (enam) tahun. Sedangkan Rencana Kerja Pemerintah Desa (RKPDesa) berlaku selama 1 (satu) tahun.

Dalam Prakteknya, mekanismen penyusunan dokumrn RPJM/RKP Desa merujuk kepada berbagai regulasi baik itu UU maupun Peraturan Mentri, pemerintah Desa berkewajiban untuk melibatkan masyarakat desa. Mekanisme pelibatan warga bisa melalui Musyawarah Desa (Musdes) atau Musyawarah Perencanaan Pembangunan Desa (Musrenbangdes). Praktek tersebut merupakan bagian dari upaya penerapan prinsip-prinsip akuntabilitas Pemerintahan Desa. Perencanaan Pembanguan yang akuntabel salah satu syaratnya adalah melibatkan masyarakat dan tersedianya akses informasi bagi masyarakat. Proses Musdes dan atau Musrenbangdesa merupakan proses counter ide dan penggalian gagasan dari tingkat bawah sebagai perwujudan aspirasi masayarakat. Proses counter ide tersebut idealnya dimulai dari tingkat dusun dan berahir ditingkat desa.

Hasil dari analisa penelitian ini menunjukkan bahwa secara keseluruhan pelibatan masyarakat dan penyampaian informasi terkait proses perencanaan dan pelaksaan pembangunan desa sudah mulai baik, walaupun masih banyak hal-hal yang perlu diperbaiki. Seperti proses penyampaian laporan terkait pelaksaan pembangunan yang telah direncanakan sebelumnya. Selain itu penerapan akuntabilitas masih mengalami hambatan akibat belum terbangunnya kesadaran masyarakat desa terkait pentingnya akuntabilitas dalam perencanaan dan pelaksaan pembangunan desa.

Pemerintah Desa sedikit banyak sudah mulai berusaha untuk mewujudkan prinsip partisipasi dan transparansi dalam perencanaan pembangunan Desa yang dapat diketahui oleh seluruh masyarakat desa melalui kegiatan Musyawarah Desa (Musdes), adapun unsur yang dilibatkan adalah Perangkat Desa, Badan Permusyawaratan Desa (BPD), Tokoh Masyarakat, Tokoh Agama, Pemuda, dan perempuan. Dengan demikian perencanaan yang disepakati juga harus transparan, dapat diketahui oleh seluruh lapisan masyarakat yang nantinya dapat dipertanggungjawabkan. Analisa terhadap data skunder menunjukkan tingkat kehadiran masayarat desa dalam kegiatan musyarawarah desa mencapai $80 \%$ dari seluruh unsur masyarakat yang diundang.

Akuntabilitas adalah kesesuaian antara aturan dan pelaksanaan kerja. Dalam pelaksanaan penyusunan perencanaan pembangunan, Pemerintah Desa Sumberngepoh selalu berusaha untuk merujuk kepada regulasi yang sudah ada. Begitu juga dalam pelaksanaannya Pemerintah Desa Sumberngepoh juga merujuk kepada regulasi dengan terus memberikan peluang kepada masyarakat desa untuk terlibat dalam kegiatan pembangunan desa.

Penerapan Akuntabilitas Proses Penyusunan Perencanaan dan pelaksaan Pembangunan terus dilakukan, walaupun masih mengalami kendala terkait sumberdaya manusia desa yang masih terbatas. Keterbatasan SDM tidak hanya terjadi dikalangan Masyarakat Desa saja, tetapi terjadi pada internal Aparat Pemerintahan desa. Kemampuan untuk menerjemahkan peraturan perundangan ke dalam bentuk praktek akuntabilitas masih mengalami hambatan, sehingga dalam prakteknya Penerapan Akuntabilitas Proses 
Penyusunan Perencanaan dan pelaksaan Pembangunan masih banyak kekurangan yang perlu diperbaiki. Sementara masyarakat desa Sumberngepoh menilai bahwa praktek akuntabilitas perencanaan pembangunan desa masih minim. Pemerintah desa masih dianggap belum terbuka. Menurut beberapa informan dari unsur masyarakat, kadangkala lokasi kegiatan pembangunan desa berubah lokasi dari usulan semula tan melaui proses musyawarah.

Sementara, penerapan Akuntabilitas Pelaksanaan Pembangunan sudah dilakukan oleh pemerintah desa Sumberngepoh, yakni dengan cara membuat papan informasi melalui Banner tentang jumlah Anggaran Pendapatan Belanja Desa (APBDesa). Untuk penyampaian informasi terkait lokasi pelaksanaan kegiatan, Pemdes Sumberngepoh sudah menyediakan dokumen perencanaan yang bisa diakses oleh masyarakat. Kemudian, disetiap lokasi kegiatan pelaksaan yang bersifat fisik (insfrastruktur), Pemerintah Desa Sumberngepoh memasang plakat yang menjelaskan tentang jenis kegiatan, volume kegiatan, jumlah anggaran, dan sumber dana yang digunakan. Selain itu pemerintah Desa Sumberngepoh juga menjadikan kegiatan musyawarah perencanaan sebagai wadah untuk menyampaikan aspirasi dan bertukar pikiran serta melibatkan seluruh lapisan masyarakat dalam proses perencanaan dan pengambilan keputusan.

Demikian juga dengan proses penerapan Akuntabilitas penyampaian laporan pelaksaan Pembangunan. Secara berkala pemerintah Desa Sumberngepoh menyampaikan laporan Realisasi Pelaksanaan Kegiatan pembangunan desa. Laporan tersebut disampaikan per-semester kepada Pemerintah Daerah. Selain itu laporan progress kegiatan juga disampaiakan kepada masyarakat melalui Badan Perwakilan Desa (BPD). Laporan berisi penggunaan anggaran Desa dan kegiatan yang sudah dilaksanakan.

Penggunaan APBDesa dalam pelaksaaana pembangunan desa sudah diatur sedemikian rupa dalam regulasi. Ada empat bidang utama kegiatan pembangunan Desa, yaitu: Pemerintahan, Pembinaan, Pembanagunan, dan Pemberdayaan. Penerapan Akuntabilitas dari sisi regulasi (Legal), pemerintah desa Sumberngepoh menggunakan sistem skala prioritas, yakni dengan menyesuaikan kebutuhan yang paling mendesak berdasarkan usulan yang dibawa oleh mayarakat dalam musyawarah desa. Ususla-usulan prioritas tersebut kemudian dimasukkan ke dalam bidang masing-masing sesuai dengan kategori kegiatan. Selanjutnya kegiatan-kegiatan tersebut akan dilaksanakan oleh PTPKD dan diawasi serta dievaluasi oleh masyarakat desa. Walaupun proses pengawasan dari masyarakat masih kurang efektif akibat pemahaman terhadap pentingnya dan tata cara pengawasan masih rendah.

Tahapan terahir dari proses penyusunan perencanaan pembangunan adalah pembuatan Peraturan Desa. Dokumen-dokumen tersebut harus di Perdeskan karena menjadi acuan dasar (legal standing) penggunaan APBDesa untuk kegiatan pembangunan Desa. Penerapan Akuntabilitas dalam pengaturan pemerintahan desa terbukukan dengan baik melalui dokumen Peraturan Desa.

\section{KESIMPULAN}

Jika yang dimaksud peran partitisipatif adalah peran dimana sikap atau perilaku yang diharapkan oleh banyak orang atau sekelompok orang terhadap seseorang yang memiliki status atau kedudukan tertentu. Apabila dihubungkan dengan peran masyarakat dalam perencanaan pembangunan desa, peran tidak berarti sebagai hak dan kewajiban individu, melainkan merupakan tugas dan wewenang masyarakat untuk terlibat dalam 


\section{REFORMASI}

proses penyusunan perencanaan pembangunan desa. Maka berdasarkan hasil analisa keseluruhan dari penelitian ini, diketahui bahwa tingkat keterlibatan warga desa Sumberngepoh dalam proses perencanaan pembangunan mengalami peningkatan, walaupun masih belum maksimal. Kertelibatan (Peran) masyarakat hanya terjadi pada elitelit desa saja. Sementara masyarakat yang sepatutnya juga terlibat belum terlibat, misalnya kelompok rentan, difabel, masyarakat marjinal, masyarakat miskin, dan kaum perempuan.

Sementara dari sisi akuntabilitas, berdasarkan analisa data diketahui bahwa penyampaian informasi terkait proses perencanaan dan pelaksaan pembangunan desa sudah mulai baik, walaupun masih banyak hal-hal yang perlu diperbaiki. Seperti proses penyampaian laporan terkait pelaksaan pembangunan yang telah direncanakan sebelumnya. Selain itu penerapan akuntabilitas masih mengalami hambatan akibat belum terbangunnya kesadaran masyarakat desa terkait pentingnya akuntabilitas dalam perencanaan dan pelaksaan pembangunan desa.

\section{DAFTAR PUSTAKA}

Amanulloh, Naeni. 2015. Buku 3: Demokratisasi Desa. Jakarta. Kementrian Desa, Pembangunan Daerah Tertinggal, dan Transmigrasi.

Bungin, Burhan. 2007. Penelitian Kualitatif. Jakarta: Prenada Media Grup.

Eko, Soetoro., dkk. 2015. Regulasi Baru Desa Baru: Ide, Misi, dan Semangat UndangUndang Desa. Jakarta. Kementrian Desa Pembangunan Daerah Tertinggal, dan Transmigrasi.

Ghozali, Dindin Abdullah. 2015. Kader Desa: Penggerak Prakarsa Masyarakat Desa. Jakarta. Kementrian Desa Pembangunan daerah.

Kessa, Wahyudin. 2015. Buku 6: Perencanaan Pembangunan Desa. Jakarta. Kementrian Desa Pembangunan Daerah Tertinggal, dan Transmigrasi.

Kurniawan, Borni. 2015. Buku 5: Desa Mandiri, Desa Membangun. Jakarta. Kementrian Desa Pembangunan daerah tertinggal, dan Transmigrasi.

Mustakim, Mochamad Zaini. 2015. Buku 2: Kepemimpinan Desa. Jakarta. Kementrian Desa, Pembangunan Daerah Tertinggal, dan Transmigrasi.

Silahuddin, M. 2015. Buku 1: Kewenangan Desa Dan Regulasi Desa. Jakarta. Kementrian Desa, Pembangunan Daerah Tertinggal, dan Transmigrasi.

\section{Peraturan Perundang-Undangan}

Peraturan Menteri Dalam Negeri No. 113 Tahun 2014 tentang Pengelolaan Keuangan Desa, Jakarta.

Peraturan Menteri Dalam Negeri No. 114 Tahun 2014 tentang Pedoman Pembangunan Desa. Jakarta.

Peraturan Pemerintah Republik Indonesia Nomor 47 Tahun 2015 tentang perubahan atas Peraturan Pemerintah Nomor 43 Tahun 2014 Tentang Peraturan Pelaksanaan Undang-Undang Nomor 6 Tahun 2014 tentang Desa.

Undang-Undang Nomor 6 Tahun 2014 tentang Desa. 